\title{
PENGARUH KINERJA TERHADAP EFEKTIVITAS PELAYANAN PADA KELURAHAN SAKO KOTA PALEMBANG
}

\section{Timbuan}

Timbuan00@gmail.com

\section{ABSTRAK}

Tujuan penelitian ini adalah untuk mengetahui dan mendeskripsikan pengaruh kinerja terhadap efektivitas pelayanan pada Kelurahan Sako Kota Palembang. Jenis penelitian yang digunakan adalah penelitian deskriptif kuantitatif yaitu pengumpulan data yang diperoleh dalam bentuk data primer dan sekunder,data diperoleh secara langsung dari narasumber (sampel) dengan fokus penelitian pada kinerja dalam memberikan pelayanan dan berkenaan dengan efektivitas pelayanan.

Dari hasil penelitian dapat diketahui bahwa kinerja mempengaruhi efektivitas pelayanan pada Kantor Lurah Sako Kota Palembang, sehingga dalam kegiatan rutin pegawai diperlukan suatu metode kerja yang baik sehingga pelayanan dapat diberikan secara maksimal pada Kantor Lurah Sako Kota Palembang.

Kata Kunci : Kinerja, efektivitas dan Pelayanan

\section{ABSTRACT}

The purpose of this study was to determine and describe the effect of performance on service effectiveness in Sako Village, Palembang City. The method of research used is descriptive quantitative research, namely the collection of data obtained in the form of primary and secondary data, data obtained directly from sources (samples) with a research focus on performance in providing services and with regard to service effectiveness. The results of the study, it can be seen that performance affects the effectiveness of services at the Sako Lurah Office, Palembang City, so that in routine employee activities it is necessary to have a good work method so that services can be provided optimally at the Sako Lurah Office, Palembang City

Keywords: Performance, effectiveness and service 


\section{PENDAHULUAN}

Citra birokrasi pemerintahan secara keseluruhan banyak ditentukan oleh kinerja organisasi tersebut. Masyarakat perkotaan yang peradabannya sudah cukup maju, mempunyai kompleksitas permasalaan lebih tinggi dibandingkan dengan masyarakat tradisional, sehingga diperlukan aparatur pelayanan yang professional. yang baik. Perlu adanya penyatuan arah dan pandangan bagi segenap jajaran Oleh karena itu, dirumuskan visi, misi, strategi, dan nilai acuan pemerintah yang menjadi pedoman mengenai arah yang dituju, beban tanggung jawab, strategi serta nilai-nilai sikap dan perilaku pegawai untuk menghadapi era globalisasi.

Dalam menghadapi era globalisasi yang penuh tantangan dan peluang, aparatur negara sebagai pelayan masyarakat yang memberikan pelayanan sebaik-baiknya menuju good governance. Pelayanan yang diberikan kepada masyarakat setiap waktu selalu menuntut pelayanan publik yang berkualitas dari birokrat yang dilakukan secara transparan dan akuntabilitas.

Pelayanan publik merupakan salah satu tugas penting yang tidak dapat diabaikan oleh pemerintah daerah, sebab jika komponen pelayanan terjadi stagnasi maka hampir dipastikan semua sektor akan berdampak kemacetan. Oleh sebab itu, perlu ada perencanaan yang baik dan bahkan perlu diformulasikan standar pelayanan pada masyarakat sesuai dengan kewenangan yang diberikan oleh pemerintah pusat pada pemerintah daerah. Sebagai konsekuensi dari pelaksanaanOtonomi Daerah setelah ditetapkannya Undang-undang Nomor : 32 Tahun 2004 tentang Pemerintahan Daerah, dimana Pemerintahan Daerah diberi kewenangan yang demikian luas oleh pemerintah pusat untuk mengatur rumah tangga daerahnya sendiri, termasuk di dalamnya adalah pemberian pelayanan kepada masyarakat di daerahnya. Namun, berbagai isu yang muncul di kalangan masyarakat, ternyata hak pelayanan yang diterima oleh masyarakat terasa belum memenuhi harapan semua pihak baik dari kalangan masyarakat umum maupun dari kalangan pemerintah sendiri. Khususnya di birokrat kelurahan dituntut untuk mampu melaksanakan fungsi utamanya, yaitu memberikan pelayanan publik yang baik dan memberikan kepuasan kepada masyarakat.

Dalam pelaksanaan tugas aparat Kelurahan sebagai birokrat di tingkat Kelurahan dituntut untuk mampu menangani kendala-kendala yang dihadapi dalam usaha-usaha pembangunan yang digalakkan pemerintah. Aparat kelurahan harus mampu melaksanakan fungsi utamanya yaitu memberikan pelayanan publik yang baik kepada masyarakat dengan peningkatan kinerja pegawai. Sehingga pelayanan yang diberikan oleh aparat kelurahan bisa memuaskan bagi masyarakat. Termasuk organisasi pemerintahan Kelurahan Sako Kota Palembang. Berdasarkan observasi awal peneliti di kantor Kelurahan Sako Kota Palembang terlihat adanya indikasi masalah, Seperti lambat pegawai dalam melayani masyarakat, banyaknya pegawai yang datang tidak tepat waktu, kurangnya sarana dan prasarana di Kelurahan Sako Kota Palembang dan masih ada pegawai yang tidak displin dalam bekerja.

Berdasarkan masalah di atas, maka peneliti tertarik untuk mengadakan penelitian dengan judul : Pengaruh Kinerja Terhadap Efektivitas Pelayanan Pada Kelurahan Sako Kota Palembang.

Berdasarkan uraaian di atas, dapat dirumuskan permasalahan yaitu bagaimana pengaruh kinerja terhadap efektivitas pelayanan pada Kelurahan Sako Kota Palembang ? 
Hipotesis merupakan jawaban sementara terhadap rumusan masalah penelitian, dimana rumusan masalah penelitian telah dinyatakan dalam bentuk kalimat pertanyaan. Dikatakan sementara,karena jawaban yangdiberikan baru didasarkan pada teori relevan, belum didasarkan pada fakta-fakta empiris yang diperoreleh melalui pengumpulan data. Jadi, hipotesis juga dapat dinyatakan jawaban teoritis terhadap rumusan penelitian belum jawaban empirik (sugiyono, 2003 : 70).

Ha: Diduga adanya pengaruh yang signifikan antara kinerja pegawai terhadap efektivitas pelayanan publik.

Ho: Diduga tidak adanya pengaruh yang signifikanantara kinerja pegawai terhadap efektivitas pelayanan publik.

Adapun untuk proses pengujian dilakukan dengan cara:

1. Tentukan hipotesis dan alternatif hipotesis :

a. Ha : Diduga adanya pengaruh yang signifikan antara kinerja pegawai terhadap efektivitas pelayanan publik.

b. Ho : Diduga tidak adanya pengaruh yang signifikan antara kinerja pegawai terhadap efektivitas pelayanan publik.

2. Untuk mengetahui seberapa besar pengaruh kinerja pegawai terhadap efektivitas pelayanan publik digunakan rumus regresi sederhana Sugiyono (2006 : 218).

$$
\mathrm{Y}=\mathrm{a}+\mathrm{bx}
$$

Keterangan :

$\mathrm{Y}=$ Subjek dari variabel dependen.

$\mathrm{a}=$ Koefisien regresi yang menunjukan bilangan konstanta.

$\mathrm{b}=$ Angka arah atau koefisien regresi yang menunjukan angka peningkatan atau penurunan variabel dependen bila $\mathrm{B}(+)$ maka terjadi kenaikan dan bila b (-) maka terjadi penurunan.
$\mathrm{X}=$ Subjek dari variabel independen yang mempunyai nilai tertentu. 


\section{TINJAUAN PUSTAKA}

\section{Pengertian Kinerja}

Kinerja menurut Mangkunegara (2007 : 67). Kinerja merupakan tingkat pencapaian hasil atas pelaksanaan tugas tertentu. Dalam konteks pengembangan sumber daya manusia kinerja seorang karyawan dalam sebuah perusahaan sangat dibutuhkan untuk mencapai prestasi kerja bagi karyawan itu sendiri dan juga untuk keberhasilan perusahaan. Istilah kinerja berasal dari job performance atau actual performance (prestasi kerja atau prestasi sesungguhnya yang dicapai oleh seseorang), atau juga hasil kerja secara kualitas dan kuantitas yang ingin dicapai oleh seorang pegawai dalam melaksanakan tugasnya sesuai dengan tanggung jawab yang diberikan kepadanya.

\section{Jenis-jenis Kriteria Kinerja}

Menurut Robbins (2002 : 155) mengatakan hampir semua cara pengukuran kinerja mempertimbangkan hal-hal sebagai berikut

1. Kuantitas yaitu jumlah yang harus diselesaikan atau dicapai. Pengukuran kuantitatif melibatkan perhitungan keluaran dari proses atau pelaksanaan kegiatan. Ini berkaitan dengan jumlah keluaran yang dihasilkan.

2. Kualitas yaitu mutu yang harus dihasilkan (baik tidaknya). Pengukuran kualitatif keluaran mencerminkan pengukuran "tingkat kepuasan", yaitu seberapa baik penyelesaiannya. Ini berkaitan dengan bentuk keluaran.

3. Ketepatan waktu yaitu sesuai tidaknya dengan waktu yang direncanakan. Pengukuran ketepatan waktu merupakan jenis khusus dari pengukuran kuantitatif yang menentukan ketepatan waktu penyelesaian suatu kegiatan.

\section{Faktor-Faktor yang Mempengaruhi Kinerja}

Faktor-faktor yang dapat mempengaruhi pencapaian kinerja adalah faktor kemampuan (ability) dan faktor motivasi (motivation) Mangkunegara (2007 : 67).

\section{Faktor kemampuan.}

Secara psikologis kemampuan terdiri dari kemampuan potensi (IQ) dan kemampuan realita, artinya karyawan yang memiliki IQ yang rata-rata (IQ 110 - 120) dengan memadai untuk jabatannya dan terampil dalam mengerjakan pekerjaannya sehari-hari, maka ia akan lebih mudah mencapai kinerja yang diharapkan.

2. Faktor motivasi.

Motivasi terbentuk dari sikap (attitude) seorang karyawan dalam menghadapi situasi kerja.

\section{Pengertian Efektivitas}

Adapun pengertian efektivitas menurut para ahli diantaranya sebagai berikut : Sondang P. Siagian (2001 : 24) memberikan definisi sebagai berikut : "Efektivitas adalah pemanfaatan sumber daya, sarana dan prasarana dalam jumlah tertentu yang secara sadar ditetapkan sebelumnya untuk menghasilkan sejumlah barang atas jasa kegiatan yang dijalankannya. Efektivitas menunjukkan keberhasilan dari segi tercapai tidaknya sasaran yang telah ditetapkan. Jika hasil kegiatan semakin mendekati sasaran, berarti makin tinggi efektivitasnya". Sementara itu Abdurahmat (2003 : 92) "Efektivitas adalah pemanfaatan sumber daya, sarana dan prasarana dalam jumlah tertentu yang secara sadar ditetapkan sebelumnya untuk menghasilkan sejumlah pekerjaan tepat pada waktunya". Dari beberapa pendapat para ahli di atas, dapat disimpulkan bahwa suatu pekerjaan 
dapat dilaksanakan secara tepat, efektif, efisien apabila pekerjaan tersebut dilaksanakan dengan tepat sesuai dengan yang telah direncanakan.

Pengertian efektivitas secara umum menunjukkan sampai seberapa jauh tercapainya suatu tujuan yang terlebih dahulu ditentukan. Hal tersebut sesuai dengan pengertian efektivitas menurut Ndraha (2005 : 163), efektivitas (effectiveness) yang didefinisikan secara abstrak sebagai tingkat pencapaian tujuan, diukur dengan rumus hasil dibagi dengan (per) tujuan. Tujuan yang bermula pada visi yang bersifat abstrak itu dapat dideduksi sampai menjadi kongkrit, yaitu sasaran (strategi). Sasaran adalah tujuan yang terukur, konsep hasil relatif, bergantung pada pertanyaan, pada mata rantai mana dalam proses dan siklus pemerintahan, hasil didefinisikan. Apakah pada titik output ? Outcome? Feedback? Siapa yang mendefinisikannya : Pemerintah, yang diperintah atau bersama-sama ?

\section{Faktor-Faktor yang Mempengaruhi Efektivitas}

Adapun faktor-faktor yang mempengaruhi efektivitas organisasi adalah sebagai berikut:

1. Adanya tujuan yang jelas.

\section{Struktur organisasi.}

3. Adanya dukungan atau partisipasi masyarakat.

4. Adanya sistem nilai yang dianut.

\section{Pelayanan Publik}

Pelayanan Publik adalah pemberian pelayanan (melayani) yang dilaksanakan oleh penyelenggara pelayanan publik sebagai upaya untuk pemenuhan kebutuhan dan keperluan penerima pelayanan atau masyarakat maupun pelaksana ketentuan peraturan perundang-undangan yang mempunyai kepentingan pada organisasi tersebut sesuai dengan aturan pokok dan tata cara yang telah di tetapkan.
Sinambela (2010 : 3), pada dasarnya setiap manusia membutuhkan pelayanan, bahkan secara ekstrim dapat dikatakan bahwa pelayanan tidak dapat dipisahkan dengan kehidupan manusia.

\section{Kualitas Pelayanan Publik}

Menurut Sinambela (2010 : 6) secara teoritis tujuan pelayanan publik pada dasarnya adalah memuaskan masyarakat. Untuk mencapai kepuasan itu dituntut kualitas pelayanan prima yang tercermin dari:

1. Transparan.

2. Akuntabilitas.

3. Kondisional.

4. Partisipatif.

5. Kesamaan hak.

6. Keseimbangan hak dan kewajiban.

\section{METODOLOGI}

Metode penelitian ini menggunakan metode kuantitatif dan menggunakan instrument penelitian kuesioner.

Pada penelitian ini, peneliti menggunakan dua jenis variabel, yaitu :

\section{Variabel Bebas (X).}

Variabel ini juga disebut Independen Variabel yaitu merupakan variabel yang mempengaruhi variabel lainnya atau menjadi sebab perubahannya atau timbulnya variabel dependen (terikat). Dalam penelitian ini variabel bebasnya yaitu Kinerja Pegawai (X).

Variabel Terikat (Y).

Variabel ini disebut Dependen Variabel yaitu variabel yang terikat yang dipengaruhi atau menjadi akibat, karena adanya variabel bebas. Dalam penelitian ini variabel terikatnya yaitu Pelayanan Publik (Y). 
Definisi operasional adalah suatu petunjuk pelaksanaan bagaimana caranya mengukur suatu variable. Adapun operasionaliasi variabel yang akan menjadi pendoman dalam penyusunan kuesioner adalah sebagai berikut:

Tabel 1

Operasionalisasi Variabel

\begin{tabular}{|c|c|c|}
\hline Variabel & Indikator-Indikator & $\begin{array}{c}\text { Nomor Butir } \\
\text { Kuesioner }\end{array}$ \\
\hline $\begin{array}{r}\text { Kinerja } \\
\text { Pegawai } \\
(\mathrm{X})\end{array}$ & $\begin{array}{l}\text { 1. Kuantitas } \\
\text { 2. Kualitas } \\
\text { 3. Ketepatan waktu } \\
\text { 4. Kemampuan } \\
\text { 5. Motivasi } \\
\text { 6. Sikap Mental }\end{array}$ & $\begin{array}{c}1 \\
2,3 \\
4,5 \\
6,7,8 \\
9 \\
10\end{array}$ \\
\hline $\begin{array}{l}\text { Pelayan } \\
\text { Publik } \\
\text { (Y) }\end{array}$ & $\begin{array}{l}\text { 1. Transparan } \\
\text { 2. Akuntabilitas } \\
\text { 3. Kondisional } \\
\text { 4. Partisipatif } \\
\text { 5. Kesamaan hak } \\
\text { 6. Keseimbangan hak dan } \\
\text { kewajiban }\end{array}$ & $\begin{array}{c}1,2 \\
3,4 \\
5,6 \\
7,8 \\
9 \\
10\end{array}$ \\
\hline
\end{tabular}

\section{Populasi dan Sampel}

Menurut sugiyono (2006 : 117) populasi adalah: "wilayah generalisasi yang terdiri atas objek / subjek yang mempunyai kuantitas dan karakteristik yang telah ditetapkan oleh peneliti untuk dipelajari dan kemudian ditarik kesimpulan". Dalam penelitian ini populasi target atau sasaran yaitu berjumlah 30 orang.

Sampel adalah sebagian atau wakil populasi yang diteliti. Tekhnik sampling yang digunakan adalah tekhnik sampling jenuh. Menurut sugiyono (2013 : 124) “sampling jenuh adalah penentuan sampel bila semua anggota populasi digunakan sebagai sampel". Dari pernyataan diatas maka penulis menggunakan semua populasisebagai sampel yaitu 30 orang.
Tabel 2

Jumlah Populasi

\begin{tabular}{|c|c|c|}
\hline No & Populasi & Jumlah \\
\hline 1 & Lurah Sako & 1 \\
\hline 2 & Sekretaris & 1 \\
\hline 3 & Babinkamtibnas & 1 \\
\hline 4 & Babinsa & 2 \\
\hline 5 & Penyuluh KB & 1 \\
\hline 6 & Kasi Pemerintah & 1 \\
\hline 7 & Kasi Trantibwil & 1 \\
\hline 8 & Kasi Pembangunan & 1 \\
\hline 9 & Kasi Kesos & 1 \\
\hline 10 & Staf & 7 \\
\hline 11 & Masyarakat Kelurahan Sako & 13 \\
\hline & Total & 30 \\
\hline
\end{tabular}

Sumber : Hasil Pengolahan Data Populasi 2020.

\section{Sampel}

Sampel adalah sebagian atau wakil populasi yang diteliti. Tekhnik sampling yang digunakan adalah tekhnik sampling jenuh. Menurut sugiyono (2013 : 124) "sampling jenuh adalah penentuan sampel bila semua anggota populasi digunakan sebagai sampel". Dari pernyataan diatas maka penulis menggunakan semua populasisebagai sampel yaitu 30 orang.

Adapun teknik pengumpulan data yang digunakan dalam penelitian ini yaitu :

\section{Data Primer}

Menurut sugiyono (2003 : 156), data primer yaitu sumber data yang langsung memberikan data kepada pengumpul data. Data primer dikumpulkan dengan teknik:

\section{Observasi.}

Kuesioner (Angket).

\section{Data Sekunder}

Menurut Sugiyono (2006: 89), yaitu data yang diperoleh dari buku, literature dan tulisan ilmiah yang berkaitan dengan penelitian ini yang telah didapat, dikumpulkan dan diberi klasifikasi.

Validitas dan reliabilitas suatu penelitian sangat tergantung dengan validitas dan reliabilitas instrumen penelitian tersebut. Validitas instrument adalah tingkat ketepatan instrumen yang akan digunakan untuk mengukur apa yang hendak diukur dalam suatu 
penelitian, sementara reliabilitas instrument adalah tingkat konsistensi pengukuran instrument.

Pengujian validitas instrument.

Pengujian validitas instrumen pada penelitian ini dilakukan dengan cara mengkorelasikan skor tiap butir, yang kemudian dianalisis dengan mengunakan rumus korelasi pearson. Menurut sugiyono (2006 : 117), syarat minimumuntuk pengujian dianggap memenuhi syarat apabila $r=0,3$ apabila skor total kurang dari 0,3 maka butir instrumen dinyatakan tidak valid.

Pengujian reliabilitas instrument.

Pengujian reliabilitas instrumen dalam penelitian ini dilakukan dengan teknik belah dua spearman brown dengan rumus sebagai berikut :

$\mathrm{ri}=2 \mathrm{rb} /(1+\mathrm{rb})$

\section{Keterangan :}

$\mathrm{ri}=$ reliabilitas seluruh instrument

$\mathrm{rb}=$ korelasi product moment antara (x) dan (y)

Dengan teknik ini butir-butir instrumen dalam penelitian ini akan dibagi menjadi dua, yaitu kelompok ganjil dan kelompok genap untuk kemudian dicapai korelasi. Setelah nilainya didapat kemudian dimasukan ke dalam rumus Spearman Brown tersebut di atas.

Data yang berhasil dikumpulkan, kemudian akan diolah dengan uji korelasi dan uji t untuk menguji hubungan variable independen / bebas dengan variabel dependen / terikat.

Sebelum dilakukan pengujian di atas, terlebih dahulu dilakukan pengujian dengan beberapa teknik untuk menganalisis data sebagai persyaratan dari uji korelasi. Berdasarkan teknik tersebut adalah sebagai berikut :

\section{Statistik Deskriptif.}

Menurut Sugiyono (2006 : 142), statistic deskriptif adalah "statistik yang digunakan untuk menganalisa data dengan cara mendeskripsikan penelitian atau menggambarkan data yang telah terkumpul sebagaimana adanya, tanpa bermaksud membuat kesimpulan yang berlaku untuk umum atau generalisasi."

Dalam penelitian ini, statistik deskriptif berdasarkan karakteristik responden, meliputi : jenis kelamin, usia, tingkat pendidikan.

Tabulasi.

Regresi Sederhana.

Analisis ini digunakan untuk mengetahui seberapa besar pengaruh kinerja pegawai terhadap efektivitas pelayanan publik digunakan rumus regresi sederhana Sugiono (2006 : 218).

$\mathrm{Y}=\mathrm{a}+\mathrm{bx}$

Untuk mendapatkan nilai a dan $\mathrm{b}$ digunakan rumus sebagai berikut :

$\mathrm{a}=\left(\left(\sum \mathrm{Y}\right)\left(\sum \mathrm{x}^{\wedge} 2\right)-\left(\sum \mathrm{X}\right)\left(\sum \mathrm{XY}\right)\right) /\left(\mathrm{n}\left(\sum \mathrm{x}^{\wedge} 2\right)-\left(\sum \mathrm{x}\right)^{\wedge} 2\right)$

$\mathrm{b}=\left(\mathrm{n} \sum \mathrm{X} . \mathrm{Y}-\left(\sum \mathrm{X}\right)\left(\sum \mathrm{Y}\right)\right) /\left(\mathrm{n} \sum \mathrm{x}^{\wedge} 2-\left(\sum \mathrm{x}^{\wedge} 2\right)\right)$

Keterangan :

$\mathrm{Y}=\quad$ Subjek dari variabel dependen

$\mathrm{a}=$ Koefisien regresi yang menunjukan bilangan konstanta

$\mathrm{b}=$ Angka arah atau koefisien regresi yang menunjukan angka peningkatan atau penurunan variabel dependen bila B (+) maka terjadi kenaikan dan bila b (-) maka terjadi penurunan.

$\mathrm{X}=$ Subjek dari variabel independen yang mempunyai nilai tertentu.

$\mathrm{n}=$ banyaknya

\section{HASIL PEMBAHASAN}

Deskripsi penelitian Responden

Responden yang menjadi sampel pada penelitian ini adalah 30 responden. Dari 30 responden tersebut dapat diketahui gambaran responden yang diteliti yaitu jenis kelamin responden, usia responden, dan pendidikan responden. Responden yang diambil ini merupakan 17 responden dari Kelurahan Sako Kota Palembang dan 13 responden dari masyarakat Kelurahan Sako Palembang yang diambil secara insidental yaitu siapa saja yang secara kebetulan bertemu dengan penelitia dapat digunakan sebagai 
sampel. Perlu dikemukakan, bahwah dari 30 kuesioner yang disebarkan semuanya mengembalikan. Dengan demikian, hasil jawaban kuesioner dari responden yang dianggap lengkap untuk dijadikan bahan analisis adalah sebanyak 30 (100\%).

Tabel 3

Distribusi Kuesioner dan Pengumpulan Data

\begin{tabular}{l|l}
\hline Jumlah responden terpilih melalui sampling jenuh & 30 \\
\hline Jumlah angket disebar & 30 \\
\hline Jumlah angket dikembalikan & 30 \\
\hline Total angket diterima kembali dari seluruh responden & $100 \%$ \\
\hline Akurasi pengisian kuesioner oleh responden & $100 \%$ \\
\hline
\end{tabular}

\section{Sumber : Data Primer (Kuesioner)}

Berikut ini adalah data-data responden secara lengkap yang akan mengisi kuesioner dengan baik.

Tabel 4

Identitas Responden $(\mathrm{n}=30)$ Berdasarkan Jenis Kelamin

\begin{tabular}{|l|l|l|l|}
\hline No & $\begin{array}{l}\text { Kelompok Jenis } \\
\text { Kelamin }\end{array}$ & Jumlah & Persen $(\%)$ \\
\hline 1 & Laki - laki & 20 & $66,67 \%$ \\
\hline 2 & Perempuan & 10 & $33,33 \%$ \\
\hline & Jumlah & 30 & $100 \%$ \\
\hline
\end{tabular}

Sumber :Hasil Pengolahan Data 2013

Berdasarkan tabel di atas, dapat diketahui jenis kelamin mayoritas responden adalah laki-laki sebanyak 20 orang $(66,67 \%)$ dan perempuan sebanyak 10 orang $(33,33 \%)$.

Tabel 5

Identitas Responden $(\mathrm{n}=30)$ Berdasarkan Usia

\begin{tabular}{|l|l|l|l|}
\hline No & Kelompok Usia & Jumlah & Persen $(\%)$ \\
\hline 1 & $17-25$ tahun & 1 & $3,33 \%$ \\
\hline 2 & $25-30$ tahun & 3 & $10 \%$ \\
\hline 3 & $30-35$ tahun & 6 & $20 \%$ \\
\hline 4 & $35-40$ tahun & 7 & $23,33 \%$ \\
\hline 5 & $>40$ tahun & 13 & $43,34 \%$ \\
\hline & Jumlah & 30 & $100 \%$ \\
\hline
\end{tabular}

Sumber :Hasil Pengolahan Data 2013

Berdasarkan tabel di atas, dapat diketahui usia mayoritas adalah di atas 40 tahun sebanyak 13 orang $(43,34 \%), 35-40$ tahun sebanyak 7 orang $(23,33 \%), 30-35$ tahun sebanyak 6 orang (20\%), 25 - 30 tahun sebanyak 3 orang (10\%), dan minoritas adalah usia 17 - 25 tahun sebanyak 1 orang $(3,33 \%)$.
Tabel 6

Identitas Responden ( $\mathrm{n}=30$ ) Berdasarkan Tingkat Pendidikan

\begin{tabular}{|l|l|l|l|}
\hline No & $\begin{array}{l}\text { Kelompok } \\
\text { Pendidikan }\end{array}$ & Frekuensi (F) & Persen (\%) \\
\hline 1 & SLTA & 9 & $30 \%$ \\
\hline 2 & Diploma & 8 & $26,6 \%$ \\
\hline 3 & S1 & 11 & $36,67 \%$ \\
\hline 4 & S2 & 2 & $6,67 \%$ \\
\hline & Total & 30 & $100 \%$ \\
\hline
\end{tabular}

Sumber :Hasil Pengolahan Data 2013

Berdasarkan tabel di atas, dapat diketahui pendidikan mayaoritas adalah dari golongan yang pendidikan strata satu (S1) sebanyak 11 orang (36,67\%), Diploma sebanyak 8 orang $(26,6 \%)$, SLTA sebanyak 9 orang $(30 \%)$, dan minoritas pendidikan strata dua (S2) sebanyak 2 orang $(6,67 \%)$.

1. Kinerja Pegawai (X)

Analisi indikator pada penelitian ini berjumlah 10 pertanyaan dan setiap jawaban dari responden akan dianalisiskan berdasarkan presentase jawaban.

1. Kuantitas kerja pegawai

Analisis indikator ini dimasukan untuk mengetahui kuantitas kerja yang dihasilkan dalam pelaksanaan kegiatan yang berlaku di kantor Kelurahan Sako Kota palembang. Untuk kategori jawaban dapat diketahui dari jawaban responden pada tabel berikut :

Tabel 7

Jawaban responden kuantitas kerja pegawai

\begin{tabular}{|l|l|l|l|}
\hline No & $\begin{array}{l}\text { Klasifikasi } \\
\text { Jawaban }\end{array}$ & Frekuensi & Persentase \\
\hline 1 & Sangat Baik & 2 & $6,7 \%$ \\
\hline 2 & Baik & 19 & $63,3 \%$ \\
\hline 3 & Cukup Baik & 9 & $30,0 \%$ \\
\hline 4 & Tidak Baik & - & - \\
\hline 5 & $\begin{array}{l}\text { Sangat Tidak } \\
\text { Baik }\end{array}$ & - & - \\
\hline & Jumlah & 30 & $100 \%$ \\
\hline
\end{tabular}

Sumber : kuesioner no. 1

Berdasarkan tabel di atas, dapat dilihat bahwa kuantitas kerja yang dihasilkan dalam pelaksanaan kegiatan dalam kategori sangat baik berjumlah 2 orang dengan persentase $6,7 \%$, responden yang menyatakan baik berjumlah 19 orang dengan persentase $63,3 \%$, dan responden yang menyatakan cukup baik berjumlah 9 orang dengan persentase 30,0\%.Berdasarkan hasil analisis tabel di atas dapat ditarik kesimpulan bahwa kuantitas kerja yang dihasilkan cukup tinggi, dapat dilihat dari sebagian besar responden berjumlah 19 orang $(63,3 \%)$ menyatakan baik. 
2. Mutu kerja yang telah ditetapkan

Analisis indikator ini dimasukkan untuk mengetahui mutu kerja yang tetapkan sesuai dengan diharapkan masyarakat. Untuk kategori jawaban dapat diketahui dari jawaban responden pada tabel berikut :

Tabel 8

Jawaban responden mutu kerja yang telah ditetapkan

\begin{tabular}{|l|l|l|l|}
\hline No & $\begin{array}{l}\text { Klasifikasi } \\
\text { Jawaban }\end{array}$ & Frekuensi & Persentase \\
\hline & $\begin{array}{l}\text { Sangat } \\
\text { Baik }\end{array}$ & 13 & $43,3 \%$ \\
\hline 2 & Baik & 17 & $56,7 \%$ \\
\hline 4 & $\begin{array}{l}\text { Cukup } \\
\text { Baik }\end{array}$ & - & - \\
\hline 4 & Tidak Baik & - & - \\
\hline 5 & $\begin{array}{l}\text { Sangat } \\
\text { Tidak Baik }\end{array}$ & - & - \\
\hline & Jumlah & 30 & $100 \%$ \\
\hline
\end{tabular}

Sumber : kuesioner no. 2

Berdasarkan tabel di atas, dapat dilihat bahwa mutu kerja yang tetapkan sesuai dengan diharapkan masyarakat dalam kategori sangat baik berjumlah 13 orang dengan persentase $43,3 \%$, dan responden yang menyatakan baik berjumlah 17 orang dengan persentase $56,7 \%$. Berdasarkan hasil analisis data di atas, dapat ditarik kesimpulan bahwa mutu kerja yang ditetapkancukup tinggi, dapat dilihat dari sebagian besar responden berjumlah 17 orang $(56,7 \%)$ menyatakan sangat baik.

Mutu kerja yang dihasilkan

Analisis indikator ini dimasukkan untuk mengetahui kualitas kerja yang dihasilkan. Untuk kategori jawaban dapat diketahui dari jawaban responden pada tabel berikut :

Tabel 9

Jawaban responden mutu kerja yang dihasilkan

\begin{tabular}{|l|l|l|l|}
\hline No & $\begin{array}{l}\text { Klasifikasi } \\
\text { Jawaban }\end{array}$ & Frekuensi & Persentase \\
\hline 1 & Sangat Baik & - & - \\
\hline 2 & Baik & 12 & $40,0 \%$ \\
\hline 3 & Cukup Baik & 13 & $43,3 \%$ \\
\hline 4 & Tidak Baik & 5 & $16,7 \%$ \\
\hline 5 & Sangat Tidak Baik & - & - \\
\hline & Jumlah & 30 & $100 \%$ \\
\hline
\end{tabular}

Berdasarkan tabel di atas, dapat dilihat bahwa kualitas kerja yang dihasilkan dalam kategori baik berjumlah 12 orang dengan persentase $40,0 \%$, responden yang menyatakan cukup baik berjumlah 13 orang dengan persentase $43,3 \%$, dan responden yang menyatakan tidak baik berjumlah 5 orang dengan persentase $16,7 \%$.Berdasarkan hasil analisis data di atas dapat ditarik kesimpulan bahwa kualitas yang dihasilkan tidak tinggi, dapat dilihat dari sebagian besar responden berjumlah 12 orang $(40,0 \%)$ menyatakan baik.

4. Ketepatan waktu dalam mengerjakan pekerjaan lembur

Analisis indikator ini dimasukkan untuk mengetahui ketepatan waktu dalam mengerjakan pekerjaan lembur. Untuk kategori jawaban dapat diketahui dari jawaban responden pada tabel berikut :

Tabel 10

Jawaban responden ketepatan waktu dalam mengerjakan pekerjaan lembur

\begin{tabular}{|l|l|l|l|}
\hline No & Klasifikasi Jawaban & Frekuensi & Persentase \\
\hline 1 & Sangat Tepat waktu & - & - \\
\hline 2 & Tepat Waktu & 15 & $50,0 \%$ \\
\hline 3 & Cukup Tepat Waktu & 13 & $43,3 \%$ \\
\hline 4 & Tidak tepat Waktu & 2 & $6,7 \%$ \\
\hline 5 & $\begin{array}{l}\text { Sangat Tidak Tepat } \\
\text { Waktu }\end{array}$ & - & - \\
\hline & Jumlah & 30 & $100 \%$ \\
\hline
\end{tabular}

Sumber : kuesioner no. 4

Berdasarkan tabel di atas, dapat dilihat bahwa ketepatan waktu dalam mengerjakan pekerjaan lembur dalam kategori tepat waktu berjumlah 15 orang dengan persentase $50,0 \%$, responden yang menyatakan cukup tepat waktu berjumlah 13 orang dengan persentase $43,3 \%$, dan responden yang menyatakan tidak tepat waktu berjumlah 2 orang dengan persentase $6,7 \%$.

Berdasarkan hasil analisis data di atas, dapat ditarik kesimpulan bahwa waktu dalam mengerjakan pekerjaan lembur cukup tinggi, dapat dilihat dari sebagian besar responden berjumlah 15 orang $(50,0 \%)$ menyatakan tepat waktu.

5. Ketepatan waktu dalam mengerjakan pekerjaan sesuai yang direncanakan

Analisis indikator ini dimasukkan untuk mengetahui ketepatan waktu dalam mengerjakan pekerjaan sesuai yang direncanakan. Untuk kategori jawaban dapat diketahui dari jawaban responden pada tabel berikut :

Tabel 11

Jawaban responden ketepatan waktu dalam 
mengerjakan

pekerjaan sesuai yang direncanakan

\begin{tabular}{|l|l|l|l|}
\hline No & Klasifikasi Jawaban & Frekuensi & Persentase \\
\hline 1 & Sangat Tepat Waktu & - & - \\
\hline 2 & Tepat Waktu & 17 & $56,7 \%$ \\
\hline 3 & Cukup Tepat Waktu & 5 & $16,7 \%$ \\
\hline 4 & Tidak Tepat Waktu & 8 & $26,7 \%$ \\
\hline 5 & Sangat Tidak Tepat Waktu & - & - \\
\hline & Jumlah & 30 & $100 \%$ \\
\hline
\end{tabular}

Sumber : kuesioner no. 5

Berdasarkan tabel di atas, dapat dilihat bahwa ketepatan waktu dalam mengerjakan pekerjaan sesuai yang direncanakan dalam kategori tepat waktu berjumlah 17 orang dengan persentase $56,7 \%$, responden yang menyatakan cukup tepat waktu berjumlah 5 orang dengan persentase $16,7 \%$, dan responden yang menyatakan tidak tepat waktu berjumlah 8 orang dengan persentase $26,7 \%$.

Berdasarkan hasil analisis data di atas, dapat ditarik kesimpulan bahwa ketepatan waktu dalam mengerjakan pekerjaan sesuai yang direncanakan cukup tinggi, dapat dilihat dari sebagian besar responden berjumlah 17 orang $(56,7 \%)$ menyatakan tepat waktu.

6. Penempatan pekerjaan sesuai keahlian / kemampuan Analisis indikator ini dimasukkan untuk mengetahui penempatan kerja sesuai keahlian / kemampuan. Untuk kategori jawaban dapat diketahui dari jawaban responden pada tabel berikut :

Tabel 12

Jawaban responden penempatan pekerjaan sesuai keahlian / kemampuan

\begin{tabular}{|l|l|l|l|}
\hline No & $\begin{array}{l}\text { Klasifikasi } \\
\text { Jawaban }\end{array}$ & Frekuensi & Persentase \\
\hline 1 & Sangat Sesuai & 9 & $30,0 \%$ \\
\hline 2 & Sesuai & 19 & $63,3 \%$ \\
\hline 3 & Cukup Sesuai & 2 & $6,7 \%$ \\
\hline 4 & Tidak Sesuai Tidak & - & - \\
\hline 5 & $\begin{array}{l}\text { Sangat } \\
\text { Sesuai }\end{array}$ & - \\
\hline & Jumlah & 30 & $100 \%$ \\
\hline
\end{tabular}

Sumber : kuesioner no. 6

Berdasarkan tabel di atas, dapat dilihat bahwa penempatan kerja sesuai keahlian dalam kategori sangat sesuai berjumlah 9 orang dengan persentase $30,0 \%$, responden yang menyatakan sesuai berjumlah 19 orang dengan persentase $63,3 \%$, dan responden yang menyatakan tidak sesuai berjumlah 2 orang dengan persentase $6,7 \%$.

Berdasarkan hasil analisis data di atas, dapat ditarik kesimpulan bahwa penempatan kerja sesuai keahlian / kemampuan cukup tinggi, dapat dilihat dari sebagian besar responden berjumlah 19 orang $(63,3 \%)$ menyatakan sesuai.

7. Kemampuan menyelesaikan pekerjaan yang dibebankan Analisis indikator ini dimasukkan untuk mengetahuikemampuan menyelesaikan pekerjaan yang dibebankan. Untuk kategori jawaban dapat diketahui dari jawaban responden pada tabel berikut :

Tabel 13

Jawaban responden kemampuan menyelesaikan pekerjaan yang dibebankan

\begin{tabular}{|l|l|l|l|}
\hline No & Klasifikasi Jawaban & Frekuensi & Persentase \\
\hline 1 & Sangat Mampu & - & - \\
\hline 2 & Mampu & 15 & $50,0 \%$ \\
\hline 3 & Cukup Mampu & 14 & $46,7 \%$ \\
\hline 4 & Tidak Mampu & 1 & 3,3 \\
\hline 5 & Sangat Tidak Mampu & - & - \\
\hline & Jumlah & 30 & $100 \%$ \\
\hline
\end{tabular}

Sumber : kuesioner no. 7

Berdasarkan tabel di atas, dapat dilihat bahwa kemampuan menyelesaikan pekerjaan yang dibebankan dalam kategori mampu berjumlah 15 orang dengan persentase $50,0 \%$, responden yang menyatakan cukup mampu berjumlah 14 orang dengan persentase $46,7 \%$.dan responden yang menyatakan tidak mampu berjumlah 1 orang dengan persentase $3,3 \%$.

Berdasarkan hasil analisis data di atas, dapat ditarik kesimpulan bahwa kemampuan menyelesaikan pekerjaan yang dibebankan cukup tinggi, dapat dilihat dari sebagian besar responden berjumlah 15 orang $(50,0 \%)$ menyatakan mampu.

8. Penyelesaian pekerjaan sesuai kemampuan Analisis indikator ini dimasukkan untuk mengetahui penyelesaian pekerjaan sesuai kemampuan. Untuk kategori jawaban dapat diketahui dari jawaban responden pada table berikut :

Tabel 14

Jawaban responden penyelesaian pekerjaan sesuai kemampuan

\begin{tabular}{|l|l|l|l|}
\hline No & Klasifikasi Jawaban & Frekuensi & Persentase \\
\hline 1 & Sangat Bisa & - & - \\
\hline 2 & Bisa & 11 & $36,7 \%$ \\
\hline 3 & Cukup Bisa & 19 & $63,3 \%$ \\
\hline 4 & Tidak Bisa & - & - \\
\hline 5 & Sangat Tidak Bisa & - & - \\
\hline & Jumlah & 30 & $100 \%$ \\
\hline
\end{tabular}

Sumber : kuesioner no. 8

Berdasarkan tabel di atas, dapat dilihat bahwa penyelesaian pekerjaan sesuai kemampuan dalam kategori bisa berjumlah 11 orang dengan persentase $36,7 \%$, dan responden yang menyatakan cukup bisa berjumlah 19 orang dengan persentase $63,3 \%$.

Berdasarkan hasil analisis data di atas, dapat ditarik kesimpulan bahwa penyelesaian pekerjaan sesuai kemampuan tidak tinggi, dapat dilihat dari sebagian 
besar responden berjumlah 11 orang $(36,7 \%)$ menyatakan bisa.

9. Daya motivasi dalam menghadapi situasi kerja

Analisis indikator ini dimasukkan untuk mengetahuidaya motivasi dalam menghadapi situasi kerja. Untuk kategori jawaban dapat diketahui dari jawaban responden pada tabel berikut :

Tabel 15

Jawaban responden daya motivasi dalam menghadapi situasi kerja

\begin{tabular}{|l|l|l|l|}
\hline No & Klasifikasi Jawaban & Frekuensi & Persentase \\
\hline 1 & Sangat baik & 2 & $6,2 \%$ \\
\hline 2 & Baik & 15 & $50,0 \%$ \\
\hline 3 & Cukup Baik & 9 & $30,0 \%$ \\
\hline 4 & Tidak Baik & 4 & $13,3 \%$ \\
\hline 5 & Sangat Tidak Baik & - & - \\
\hline & Jumlah & 30 & $100 \%$ \\
\hline
\end{tabular}

Sumber : kuesioner no.9

Berdasarkan tabel di atas, dapat dilihat bahwa daya motivasi dalam menghadapi situasi kerja dalam kategori sangat baik berjumlah 2 orang dengan persentase $6,7 \%$, responden yang menyatakan baik berjumlah 15 orang dengan persentase $50,0 \%$, responden yang menyatakan cukup baik berjumlah 9 orang dengan persentase $30,0 \%$, dan responden yang menyatakan tidak baik berjumlah 4 orang dengan persentase $13,3 \%$. Berdasarkan hasil analisis data di atas, dapat ditarik kesimpulan bahwa daya motivasi dalam menghadapi situasi kerja cukup tinggi, dapat dilihat dari sebagian besar responden berjumlah 15 orang $(50,0)$ menyatakan baik.

10. Sikap mental untuk mendorong diri mencapai prestasi kerja maksimal

Analisis indikator ini dimasukan untuk mengetahui sikap mental untuk mendorong diri mencapai prestasi kerja maksimal. Untuk kategori jawaban dapat diketahui dari jawaban responden pada tabel berikut :

Tabel 16

Jawaban responden sikap mental untuk mendorong diri mencapai prestasi kerja maksimal

\begin{tabular}{|l|l|l|l|}
\hline No & $\begin{array}{l}\text { Klasifikasi } \\
\text { Jawaban }\end{array}$ & Frekuensi & Persentase \\
\hline 1 & Sangat Punya & - & - \\
\hline 2 & Punya & 14 & $46,7 \%$ \\
\hline 3 & Cukup Punya & 9 & $30,0 \%$ \\
\hline 4 & Tidak Punya & 7 & $23,3 \%$ \\
\hline 5 & $\begin{array}{l}\text { Sangat Tidak } \\
\text { Punya }\end{array}$ & - & - \\
\hline & Jumlah & 30 & $100 \%$ \\
\hline
\end{tabular}

Sumber : kuesioner no. 10

Berdasarkan tabel di atas, dapat dilihat bahwa sikap mental untuk mendorong diri mencapai prestasi kerja maksimal dalam kategori punya berjumlah 14 orang dengan persentase $46,7 \%$, responden yang menyatakan cukup punya berjumlah 9 orang dengan persentase $30,0 \%$, dan responden yang menyatakan tidak punya berjumlah 7 orang dengan persentase $23,3 \%$. Berdasarkan hasil analisis data di atas dapat ditarik kesimpulan bahwa sikap mental untuk mendorong diri mencapai prestasi kerja maksimal tidak tinggi, dapat dilihat dari sebagian besar responden berjumlah 14 orang $(46,7 \%)$ menyatakan punya.

\section{PelayananPublik (Y)}

Analisis indikator pada penelitian ini berjumlah 10 pertanyaan dan setiap jawaban dari responden akan dianalisiskan berdasarkan presentase jawaban.

1. Sifat terbuka dalam melayani masyarakat Analisis indikator ini dimasukan untuk mengetahuisifat terbuka dalam melayani masyarakat. Untuk kategori jawaban dapat diketahui dari jawaban responden pada tabel berikut :

\section{Tabel 17}

Jawaban responden sifat terbuka dalam melayani masyarakat

\begin{tabular}{|l|l|l|l|}
\hline No & $\begin{array}{l}\text { Klasifikasi } \\
\text { Jawaban }\end{array}$ & Frekuensi & Persentase \\
\hline 1 & $\begin{array}{l}\text { Sangat } \\
\text { Terbuka }\end{array}$ & - & - \\
\hline 2 & Terbuka & 20 & $66,7 \%$ \\
\hline 3 & $\begin{array}{l}\text { Cukup } \\
\text { Terbuka }\end{array}$ & 10 & $33,3 \%$ \\
\hline 4 & Tidak Terbuka & - & - \\
\hline 5 & $\begin{array}{l}\text { Sangat Tidak } \\
\text { Terbukas }\end{array}$ & - & - \\
\hline & Jumlah & 30 & $100 \%$ \\
\hline
\end{tabular}

Sumber : kuesioner no. 1

Berdasarkan tabel di atas, dapat dilihat bahwa sifat terbuka dalam melayani masyarakat dalam kategori terbuka berjumlah 20 orang dengan persentase $66,7 \%$, dan responden yang menyatakan cukup terbuka berjumlah 10 orang dengan persentase $33,3 \%$. Berdasarkan hasil analisis data di atas, dapat ditarik kesimpulan bahwa sifat terbuka dalam melayani masyarakat cukup tinggi, dapat dilihat dari sebagian besar responden berjumlah 20 orang $(66,7 \%)$ menyatakan terbuka.

2. Pelayanan yang diberikan mudah dan dapat di akses dengan cepat oleh masyarakat

Analisis indikator ini dimasukkan untuk mengetahuipelayanan yang diberikan mudah dan dapat di akses dengan cepat oleh masyarakat. Untuk kategori jawaban dapat diketahui dari jawaban responden pada tabel berikut :

\section{Tabel 18}

Jawaban Responden Pelayanan yang diberikan mudah dan dapat diakses dengan cepat oleh masyarakat

\begin{tabular}{|l|l|l|l|}
\hline No & Klasifikasi & Frekuensi & Persentase \\
\hline
\end{tabular}




\begin{tabular}{|l|l|l|l|}
\hline & Jawaban & & \\
\hline 1 & Sangat Mudah & 12 & $40,0 \%$ \\
\hline 2 & Mudah & 18 & $60,0 \%$ \\
\hline 3 & Cukup Mudah & - & - \\
\hline 4 & Tidak Mudah & - & - \\
\hline 5 & $\begin{array}{l}\text { Sangat Tidak } \\
\text { Mudah }\end{array}$ & - & - \\
\hline & Jumlah & 30 & $100 \%$ \\
\hline
\end{tabular}

Sumber : kuesioner no. 2

Berdasarkan tabel di atas, dapat dilihat bahwa pelayanan yang diberikan mudah dan dapat di akses dengan cepat oleh masyarakat dalam kategori sangat mudah berjumlah 12 orang dengan persentase $40,0 \%$, dan responden yang menyatakan mudah berjumlah 18 orang dengan persentase $60,0 \%$.Berdasarkan hasil analisis data di atas, dapat ditarik kesimpulan bahwa pelayanan yang diberikan mudah dan dapat di akses dengan cepat oleh masyarakat cukup tinggi, dapat dilihat dari sebagian besar responden berjumlah 18 orang $(60,0 \%)$ menyatakan mudah.

3. Pelayanan publik yang sesuai dengan ketentuan Peraturan Perundang- undangan

Analisis indikator ini dimasukkan untuk mengetahui pelayanan publik yang harus mengacu pada undang-undang. Untuk kategori jawaban dapat diketahui dari jawaban responden pada tabel berikut :

Tabel 19

Jawaban responden pelayanan publik yang sesuai dengan ketentuan

Peraturan Perundang - undangan

\begin{tabular}{|l|l|l|l|}
\hline No & $\begin{array}{l}\text { Klasifikasi } \\
\text { Jawaban }\end{array}$ & Frekuensi & Persentase \\
\hline 1 & Sangat Sesuai & - & - \\
\hline 2 & Sesuai & 21 & $70,0 \%$ \\
\hline 3 & Cukup Sesuai & 9 & $30,0 \%$ \\
\hline 4 & Tidak Sesuai & - & - \\
\hline 5 & $\begin{array}{l}\text { Sangat Tidak } \\
\text { Sesuai }\end{array}$ & - & - \\
\hline & Jumlah & 30 & $100 \%$ \\
\hline
\end{tabular}

Sumber : kuesioner no. 3

Berdasarkan tabel di atas, dapat dilihat bahwa pelayanan publik yang sesuaidengan ketentuan perundang-undangan dalam kategori sesuai berjumlah 21 orang dengan persentase $70,0 \%$, dan responden yang menyatakan cukup sesuai berjumlah 9 orang dengan persentase 30,0\%. Berdasarkan hasil analisis data di atas. dapat ditarik kesimpulan bahwa pelayanan publik yang harus mengacu pada Undang-undang cukup tinggi, dapat dilihat dari sebagian besar responden berjumlah 21 orang $(70,0 \%)$ menyatakan sesuai.

4. Pelayanan publik yang dapat di pertanggung jawabkan Analisis indikator ini dimasukkan untuk mengetahuipelayanan publik yang dapat di pertanggung jawabkan. Untuk kategori jawaban dapat diketahui dari jawaban responden pada tabel berikut :
Tabel 20

Jawaban responden pelayanan publik yang dapat di pertanggung jawabkan

\begin{tabular}{|l|l|l|l|}
\hline No. & $\begin{array}{l}\text { Klasifikasi } \\
\text { Jawaban }\end{array}$ & Frekuensi & Persentase \\
\hline 1 & Sangat Bisa & - & - \\
\hline 2 & Bisa & 27 & $90,0 \%$ \\
\hline 3 & Cukup Bisa & 3 & $10,0 \%$ \\
\hline 4 & Tidak Bisa & - & - \\
\hline 5 & $\begin{array}{l}\text { Sangat Tidak } \\
\text { Bisa }\end{array}$ & - & - \\
\hline & Jumlah & 30 & $100 \%$ \\
\hline
\end{tabular}

Sumber : kuesioner no. 4

Berdasarkan tabel di atas, dapat dilihat bahwa pelayanan publik yang dapat di pertanggung jawabkan dalam kategori bisa berjumlah 27 orang dengan persentase $90,0 \%$, dan responden yang menyatakan cukup bisa berjumlah 3 orang dengan persentase 10,0\%.Berdasarkan hasil analisis data di atas, dapat ditarik kesimpulan bahwa pelayanan publik yang dapat dipertanggung jawabkan sangat tinggi, dapat dilihat dari sebagian besar responden berjumlah 27 orang $(90,0 \%)$ menyatakan bisa.

5. Pelayanan yang sesuaidengan kondisi masyarakat

Analisis indikator ini dimasukkan untuk mengetahui pelayanan yang sesuai dengan kondisi masyarakat. Untuk kategori jawaban dapat diketahui dari jawaban responden pada tabel berikut :

Tabel 21

Jawaban responden pelayanan yang sesuai dengan kondisi masyarakat

\begin{tabular}{|l|l|l|l|}
\hline No & $\begin{array}{l}\text { Klasifikasi } \\
\text { Jawaban }\end{array}$ & Frekuensi & Persentase \\
\hline 1 & Sangat Sesuai & 23 & $76,7 \%$ \\
\hline 2 & Sesuai & 7 & $23,3 \%$ \\
\hline 3 & Cukup Sesuai & - & - \\
\hline 4 & Tidak Sesuai & - & - \\
\hline 5 & $\begin{array}{l}\text { Sangat Tidak } \\
\text { Sesuai }\end{array}$ & - & - \\
\hline & Jumlah & 30 & $100 \%$ \\
\hline
\end{tabular}

Sumber : kuesioner no. 5

Berdasarkan tabel di atas, dapat dilihat bahwa pelayanan yang sesuai dengan kondisi masyarakat dalam kategori sangat sesuai berjumlah 23 orang dengan persentase $76,7 \%$, dan responden yang menyatakan sesuai berjumlah 7 orang dengan persentase $23,3 \%$. Berdasarkan hasil analisis data di atas dapat ditarik kesimpulan bahwa pelayanan yang sesuai dengan kondisi masyarakat tidak tinggi, dapat dilihat dari sebagian besar responden berjumlah 23 orang $(76,7 \%)$ menyatakan sesuai. 
6. Pelayanan yang sesuai dengan kondisi masyarakat Analisis indikator ini dimasukkan untuk mengetahui pelayanan yang sesuai dengan kondisi masyarakat. Untuk kategori jawaban dapat diketahui dari jawaban responden pada tabel berikut :

Tabel 22

Jawaban responden pelayanan yang sesuai dengan kondisi masyarakat

\begin{tabular}{|l|l|l|l|}
\hline No & $\begin{array}{l}\text { Klasifikasi } \\
\text { Jawaban }\end{array}$ & Frekuensi & Persentase \\
\hline 1 & Sangat Sesuai & - & - \\
\hline 2 & Sesuai & 20 & $66,7 \%$ \\
\hline 3 & Cukup Sesuai & 10 & $33,3 \%$ \\
\hline 4 & Tidak Sesuai & - & - \\
\hline 5 & $\begin{array}{l}\text { Sangat Tidak } \\
\text { Sesuai }\end{array}$ & - & - \\
\hline & Jumlah & 30 & $100 \%$ \\
\hline
\end{tabular}

Sumber : kuesioner no. 6

Berdasarkan tabel di atas, dapat dilihat bahwa pelayanan yang sesuai dengan kondisi masyarakat dalam kategori sesuai berjumlah 20 orang dengan persentase $66,7 \%$, dan responden yang menyatakan cukup sesuai berjumlah 10 orang dengan persentase $33,3 \%$. Berdasarkan hasil analisis data di atas, dapat ditarik kesimpulan bahwa kemampuan maksimal pegawai dalam memberikan pelayanan publik cukup tinggi, dapat dilihat dari sebagian besar responden berjumlah 20 orang $(66,7 \%)$ menyatakan sesuai.

7. Menerima dan memperhatikan aspirasi masyarakat Analisis indikator ini dimasukkan untuk mengetahui, menerima, dan memperhatikan aspirasi masyarakat. Untuk kategori jawaban dapat diketahui dari jawaban responden pada tabel berikut :

Tabel 23

Jawaban responden menerima dan memperhatikan aspirasi masyarakat

\begin{tabular}{|l|l|l|l|}
\hline No & $\begin{array}{l}\text { Klasifikasi } \\
\text { Jawaban }\end{array}$ & Frekuensi & Persentase \\
\hline 1 & Sangat Baik & 13 & $43,3 \%$ \\
\hline 2 & Baik & 17 & $56,7 \%$ \\
\hline 3 & Cukup Baik & - & - \\
\hline 4 & Tidak Baik & - & - \\
\hline 5 & $\begin{array}{l}\text { Sangat Tidak } \\
\text { Baik }\end{array}$ & - & - \\
\hline & Jumlah & 30 & $100 \%$ \\
\hline
\end{tabular}

Berdasarkan tabel di atas, dapat dilihat bahwa menerima dan memperhatikan aspirasi masyarakat dalam kategori sangat baik berjumlah 13 orang dengan persentase $43,3 \%$, dan responden yang menyatakan baik berjumlah 17 orang dengan persentase $56,7 \%$. Berdasarkan hasil analisis data di atas, dapat ditarik kesimpulan bahwa menerima dan memperhatikan aspirasi masyarakat cukup tinggi, dapat dilihat dari sebagian besar responden berjumlah 17 orang $(56,7 \%)$ menyatakan baik.
8. Realisasi kebutuhan dan harapan masyarakat Analisis indikator ini dimasukkan untuk mengetahui realisasi kebutuhan dan harapan masyarakat. Untuk kategori jawaban dapat diketahui dari jawaban responden pada tabel berikut :

Tabel 24

Jawaban responden realisasi kebutuhan dan harapan masyarakat

\begin{tabular}{|l|l|l|l|}
\hline No & $\begin{array}{l}\text { Klasifikasi } \\
\text { Jawaban }\end{array}$ & Frekuensi & Persentase \\
\hline 1 & Sangat Baik & 6 & $20,0 \%$ \\
\hline 2 & Baik & 13 & $43,3 \%$ \\
\hline 3 & Cukup Baik & 11 & $36,7 \%$ \\
\hline 4 & Tidak Baik & - & - \\
\hline 5 & $\begin{array}{l}\text { Sangat Tidak } \\
\text { Baik }\end{array}$ & - & - \\
\hline & Jumlah & 30 & $100 \%$ \\
\hline
\end{tabular}

Sumber : kuesioner no. 8

Berdasarkan tabel di atas, dapat dilihat bahwa realisasi kebutuhan dan harapan masyarakat dalam kategori sangat baik berjumlah 6 orang dengan persentase $20,0 \%$, responden yang menyatakan baik berjumlah 13 orang dengan persentase $43,3 \%$, dan responden yang menyatakan cukup baik berjumlah 11 orang dengan persentase $36,7 \%$.

Berdasarkan hasil analisis data di atas, dapat ditarik kesimpulan bahwa realisasi kebutuhan dan harapan masyarakat sudah tidak tinggi, dapat dilihat dari sebagian besar responden berjumlah 13 orang $(43,3 \%)$ menyatakan baik.

9. Kesamaan hak

Analisis indikator ini dimasukan untuk mengetahuikesamaan hak. Untuk kategori jawaban dapat diketahui dari jawaban responden pada tabel berikut :

Tabel 25

Jawaban responden kesamaan hak

\begin{tabular}{|l|l|l|l|}
\hline No & $\begin{array}{l}\text { Klasifikasi } \\
\text { Jawaban }\end{array}$ & Frekuensi & Persentase \\
\hline 1 & Sangat Sesuai & - & - \\
\hline 2 & Sesuai & 18 & $60,0 \%$ \\
\hline 3 & Cukup Sesuai & 12 & $40,0 \%$ \\
\hline 4 & Tidak Sesuai & - & - \\
\hline 5 & $\begin{array}{l}\text { Sangat Tidak } \\
\text { Sesuai }\end{array}$ & - & - \\
\hline & Jumlah & 30 & $100 \%$ \\
\hline
\end{tabular}

Sumber : kuesioner no. 9

Berdasarkan tabel di atas, dapat dilihat bahwa kesamaan hak dalam kategori sesuai berjumlah 18 orang dengan persentase $60,0 \%$, dan responden yang menyatakan cukup sesuai berjumlah 12 orang dengan persentase 
40,0\%. Berdasarkan hasil analisis data di atas, dapat ditarik kesimpulan bahwa kesamaan hak cukup tinggi, dapat dilihat dari sebagian besar responden berjumlah 18 orang $(60,0 \%)$ menyatakan sesuai.

10. Keseimbangan hak dan kewajiban

Analisis indikator ini dimasukan untuk mengetahui keseimbangan hak dan kewajiban. Untuk kategori jawaban dapat diketahui dari jawaban responden pada tabel berikut :

Tabel 26

Jawaban responden keseimbangan hak dan kewajiban

\begin{tabular}{|l|l|l|l|}
\hline No & $\begin{array}{l}\text { Klasifikasi } \\
\text { Jawaban }\end{array}$ & Frekuensi & Persentase \\
\hline 1 & Sangat baik & - & - \\
\hline 2 & Baik & 8 & $26,7 \%$ \\
\hline 3 & Cukup baik & 17 & $56,7 \%$ \\
\hline 4 & Tidak baik & 5 & $16,7 \%$ \\
\hline 5 & Sangat Tidak baik & - & - \\
\hline & Jumlah & 30 & $100 \%$ \\
\hline
\end{tabular}

Sumber : kuesioner no. 10

Berdasarkan tabel di atas, dapat dilihat bahwa keseimbangan hak dan kewajiban dalam kategori baik berjumlah 8 orang dengan persentase $26,7 \%$, responden yang menyatakan cukup baik berjumlah 17 orang dengan persentase $56,7 \%$, dan responden yang menyatakan tidak baik berjumlah 5 orang dengan persentase $16,7 \%$.

Berdasarkan hasil analisis data di atas dapat ditarik kesimpulan bahwa keseimbangan hak dan kewajiban sangat tidak tinggi, dapat dilihat dari sebagian besar responden berjumlah 8 orang $(26,7 \%)$ menyatakan baik.

2. Analisis Kinerja Pegawai

Setelah dilakukan analisis dari 10 instrumen yang valid terkait dengan kinerja pegawai yang diberikan kepada anggota sampel yaitu 30 responden, maka didapatkan hasil sebagai berikut $\mathrm{x} 30=1500$

Bila setiap butir mendapatkan skor tertinggi yaitu : $5 \times 10$

b. $\quad$ Bila setiap butir mendapatkan skor terendah yaitu : $1 \times 10$ $\mathrm{x} 30=300$

Keterangan :

$$
\begin{array}{ll}
5 & =\text { Nilai skor tertinggi } \\
1 & =\text { Nilai skor terendah } \\
30 & =\text { Jumlah responden } \\
1079 & =\text { Jumlah skor pengumpulan data }(X)
\end{array}
$$

Menurut 30 responden mengenai analisis kinerja pegawai yaitu : $\sum$ Kuesioner

$$
\overline{\sum \text { Responden }} \times 100 \%
$$

Berdasarkan perhitungan dan keterangan di atas, dapat diketahui bahwa kinerja pegawai sangat diperlukan dan harus ditingkatkan agar tercipta dan terwujudnya tingkat kepuasan masyarakat terhadap pelayanan yang diberikan oleh Kelurahan Sako Kota Palembang. Hal itu dapat dilihat dari nilai $1079(71,93 \%)$ termasuk kategori kontinium "Cukup Baik" dan hampir menyentuh kategori kontinium "Baik" jadi kesimpulannya kinerja pegawaidalam memberikan pelayanan publik diKelurahan Sako Kota Palembang termasuk kategori "Cukup Baik".

\section{Analisis Pelayanan Publik}

Setelah dilakukan analisis dari 8 instrumen yang valid terkait dengan pelayanan publik yang diberikan kepada anggota sampel yaitu 30 responden, maka didapatkan hasil sebagai berikut :

a. Bila setiap butir mendapatkan skor tertinggi yaitu : $5 \times 8 \times 30=1200$

b. Bila setiap butir mendapatkan skor terendah yaitu : $1 \times 8 \times 30=240$

\section{Keterangan :}

$5=$ Nilai skor tertinggi

$1=$ Nilai skor terendah

$30=$ Jumlah responden

$936=$ Jumlah skor pengumpulan data $(\mathrm{Y})$

Menurut 30 responden mengenai analisis pelayanan publik yaitu :

$\sum$ Kuesioner

$\sum$ Responden $\times 100 \%$

936

1200

Berdasar pada perhitungan dan keterangan di atas, dapat diketahui bahwa Tingkat kepuasan sangat dibutuhkan agar masyarakat yang menerima pelayanan dikelurahan Sako Kota Palembang dapat merasa puas dan kepentingan masyarakat dapat terwujud sesuai dengan harapan yang diinginkan masyarakat. Untuk itu kinerja pegawai pada Kelurahan Sako Kota Palembang terusditingkatkan dan perbaikan secara terus menerus agar dapat menghasilakn kinerja yang lebih baik lagi. Hal ini dapat dilihat dari nilai $936(78,0 \%)$ termasuk kategori kontinium "Cukup Baik" hampir menyentuh kategori kontinium "Baik" jadi kesimpulannya pelayanan publik yang diberikan Kelurahan Sako Kota Palembang termasuk dalam kategori "Cukup Baik".

Uji validilitas instrumen digunakan untuk mengukur sah atau valid tidaknya suatu kuesioner. Suatu kuesioner dikatakan valid jika pertanyaan pada kuesioner mampu untuk mengungkapkan suatu yang akan diukur oleh kuesioner tersebut. Pengujian validilitas instrument pada penelitian ini dilakukan dengan cara mengkorelasikan skor stiap butir dengan 
skor total total yang merupakan jumlah skor tiap butir yang kemudian dianalisiskan dengan mengunanakan SPSS 12 for windows rumus korelasi peatson. Syarat minimum untuk suatu pengujian dianggap memenuhi syarat adalah jika $\mathrm{r}=0,361$. Apabila skor total kurang dari 0,361 maka butir instrument tersebut dinyatakan tidak valid.

Tabel 27

Uji Validilitas InstrumenKinerja Pegawai (X)

\begin{tabular}{|l|l|l|l|l|}
\hline Item & $\mathrm{r}($ hitung) & & $\mathrm{r}($ tabel $)$ & Keterangan \\
\hline 1 & 0,487 & $>$ & 0,361 & Valid \\
\hline 2 & 0,543 & $>$ & 0,361 & Valid \\
\hline 3 & 0,616 & $>$ & 0,361 & Valid \\
\hline 4 & 0,615 & $>$ & 0,361 & Valid \\
\hline 5 & 0,639 & $>$ & 0,361 & Valid \\
\hline 6 & 0,429 & $>$ & 0,361 & Valid \\
\hline 7 & 0,593 & $>$ & 0,361 & Valid \\
\hline 8 & 0,538 & $>$ & 0,361 & Valid \\
\hline 9 & 0,402 & $>$ & 0,361 & Valid \\
\hline 10 & 0,719 & $>$ & 0,361 & Valid \\
\hline
\end{tabular}

Sumber : SPSS For Windows Versi. 20

Berdasarkan hasil uji validilitas instrumen kinerja pegawai pada tabel di atas, diketahui bahwa semua butir yang digunakan pada variabel kinerja pegawai adalah valid. Adapun butir yang mempunyai validitas tertinggi adalah butir 10 dengan koefisien korelasi 0,719, sedangkan yang memiliki validitas terendah adalah butir 9 dengan koefisien korelasi sebesar 0,402

Tabel 28

Uji Validilitas Instrumen Pelayanan Publik (Y)

\begin{tabular}{|l|l|l|l|l|}
\hline Item & $\mathrm{r}($ hitung) & & $\mathrm{r}($ tabel $)$ & Keterangan \\
\hline 1 & 0,521 & $>$ & 0,361 & Valid \\
\hline 2 & 0,486 & $>$ & 0,361 & Valid \\
\hline 3 & 0,396 & $>$ & 0,361 & Valid \\
\hline 4 & 0,428 & $>$ & 0,361 & Valid \\
\hline 5 & $0,-020$ & $>$ & 0,361 & Tidak Valid \\
\hline 6 & 0,487 & $>$ & 0,361 & Valid \\
\hline 7 & 0,478 & $>$ & 0,361 & Valid \\
\hline 8 & 0,690 & $>$ & 0,361 & Valid \\
\hline 9 & 0,505 & $>$ & 0,361 & Valid \\
\hline 10 & 0,188 & $>$ & 0,361 & Tidak Valid \\
\hline
\end{tabular}

Sumber : SPSS For Windows Versi. 12

Berdasarkan hasil uji validilitas instrumen pelayanan publik pada tabel di atas, diketahui bahwa tidak semua pertanyaan kuesioner valid, yaitu pertanyaan butir 5 dan 10 memiliki hasil yang tidak valid dan pertanyaan yang tidak valid tidak akan dimasukan ke dalam perhitungan selanjutnya. Adapun butir yang mempunyai validitas tertinggi adalah butir 8 dengan koefisien korelasi 0,690 , sedangkan yang memiliki validitas terendah adalah butir 5 dengan koefisien korelasi sebesar 0,-020.

Uji reliabilitas instrumen digunakan untuk mengukur keterandalan instrumen. Keterandalan instrumen adalah konsistensi, stabilitas, kepercayaan dan daya prediksi terhadap hasil pengukuran dengan menggunakan instrument tersebut. Dengan demikian instrumen-instrumen tersebut dapat menjaring data untuk mengungkapkan tujuan penelitian.

Instrumen penelitian dikatakan reliable jika memiliki nilai alpha lebih besar dari 0,60. Untuk menguji reliabilitas instrumen digunakan koefisien reliability Alpha Cronbachyang perhitungannya menggunakan prosedur reliabilitas pada program SPSS For Windows Versi 20

Tabel 29

Koefisien Reliabilitas Alpha Cronbach Case Processing Summary

\begin{tabular}{|ll|l|l|}
\hline & & $\mathrm{N}$ & $\%$ \\
\hline Cases & Valid & 30 & 100.0 \\
& Excluded( & 0 & .0 \\
& a) & 30 & 100.0 \\
\hline
\end{tabular}

a Listwise deletion based on all variables in the procedure.

Reliability Statistics

\begin{tabular}{|l|l|}
\hline $\begin{array}{l}\text { Cronbach's } \\
\text { Alpha }\end{array}$ & $\begin{array}{l}\mathrm{N} \\
\text { Items }\end{array}$ \\
\hline .821 & 18 \\
\hline
\end{tabular}

Berdasarkan perhitungan uji reliabilitas untuk 30 jawaban responden dari 18 pertanyaan yang telah lolos seleksi uji validilitas instrumen ternyata diperoleh nilai alpha sebesar 0.821. Dengan demikian $0.821>0.60$. Maka, pertanyaan pada penelitian ini adalah reliable (jawaban responden adalah kosisten sehingga dapat dijadikan sebagai alat ukur dalam mengukur variabel penelitian).

Digunakan untuk mengetahui pengaruh antara variabel bebas $(\mathrm{X})$ terhadap variabel terikat $(\mathrm{Y})$ menggunakan program SPSS For Windows Versi 20

Tabel 30

Perhitungan Regresi dari Semua Variabel yang Diteliti Model Summary

\begin{tabular}{|c|c|c|c|c|}
\hline $\begin{array}{l}\text { Mod } \\
\text { el }\end{array}$ & $\mathrm{R}$ & $\begin{array}{l}\mathrm{R} \\
\text { Squa } \\
\text { re }\end{array}$ & $\begin{array}{l}\text { Adjust } \\
\text { ed R } \\
\text { Square }\end{array}$ & $\begin{array}{l}\text { Std. } \\
\text { Error } \\
\text { of the } \\
\text { Estima } \\
\text { te }\end{array}$ \\
\hline 1 & $\begin{array}{l}.660( \\
\text { a) }\end{array}$ & .435 & .415 & 1.674 \\
\hline
\end{tabular}

a Predictors: (Constant), Kinerja_Pegawai

$\operatorname{ANOVA}(\mathrm{b})$

\begin{tabular}{|l|l|l|l|l|l|l|}
\hline $\begin{array}{l}\text { Mod } \\
\text { el }\end{array}$ & & $\begin{array}{l}\text { Sum } \\
\text { of }\end{array}$ & & Mean & & \\
Square & D & Squar & & \\
S & f & F & Sig. \\
\hline
\end{tabular}


pengembangan sumber daya manusia kinerja seorang karyawan dalam sebuah perusahaan sangat dibutuhkan untuk mencapai prestasi kerja bagi karyawan itu sendiri dan juga untuk keberhasilan perusahaan. Istilah kinerja berasal dari job performance atau actual performance (prestasi kerja atau prestasi sesungguhnya yang dicapai oleh seseorang), atau juga hasil kerja secara kualitas dan kuantitas yang ingin dicapai oleh seorang pegawai dalam melaksanakan tugasnya sesuai dengan tanggung jawab yang diberikan kepadanya (Mangkunegara, 2007 : 67).

Menurut Robbins (2002 : 155) mengatakan hampir semua cara pengukuran kinerja mempertimbangkan hal-hal sebagai berikut :

1. Kuantitas yaitu jumlah yang harus diselesaikan atau dicapai. Pengukuran kuantitatif melibatkan perhitungan keluaran dari proses atau pelaksanaan kegiatan. Ini berkaitan dengan jumlah keluaran yang dihasilkan.

2. Kualitas yaitu mutu yang harus dihasilkan (baik tidaknya). Pengukuran kualitatif keluaran mencerminkan pengukuran "tingkat kepuasan", yaitu seberapa baik penyelesaiannya. Ini berkaitan dengan bentuk keluaran.

3. Ketepatan waktu yaitu sesuai tidaknya dengan waktu yang direncanakan. Pengukuran ketepatan waktu merupakan jenis khusus dari pengukuran kuantitatif yang menentukan ketepatan waktu penyelesaian suatu kegiatan.

Berdasarkan landasaran teori di atas, ketepatan waktu yang harus ditingkatkan, agar kinerja pegawai dapat atau mampu menciptakan kuantitas dan mutu pelayanan publik yang baik dan tepat waktu sesuai yang diharapkan masyarakat yang menerima pelayanan dari Kantor Kelurahan Sako Kota Palembang.

Tingkat pelayanan publik pada kantor Kelurahan Sako Kota Palembang termasuk dalam kategori cukup baik dengan kriteria $78,0 \%$. Artinya walaupun pelayanan yang diberikan belum bisa terpenuhi secara maksimal akan tetapi pelayanan yang diberikan oleh Kantor Kelurahan Sako Kota Palembang sudah cukup baik. Hal ini dikarenakan masih kurangnyakemampuan dan motivasi diri pegawai untuk memaksimalkan seluruh kemampuannya untuk memenuhi kebutuhan masyarakat dengan tepat waktu.

Menurut Sinambela (2010 : 6) secara teoritis tujuan pelayanan publik pada dasarnya adalah memuaskan masyarakat. Untuk mencapai kepuasan itu dituntut kualitas pelayanan prima yang tercermin dari :

1. Transparan.

Pelayanan yang bersifat terbuka, mudah dan dapat diakses oleh semua pihakyang membutuhkan dan disediakan secara memadai serta mudah dimengerti.

2. Akuntabilitas.

Pelayanan yang dapat dipertanggungjawabkan sesuai dengan ketentuanperaturan perundang-undangan.

3. Kondisional.

Pelayanan yang sesuai dengan kondisi dan kemampuan pemberi dan penerimapelayanan dengan tetap berpegang pada prinsip efisiensi dan efektivitas.

4. Partisipatif.

Pelayanan yang dapat mendorong peran serta masyarakat dalampenyelenggaraan pelayanan publik dengan memperhatikan aspirasi, kebutuhan dan harapan masyarakat.

5. Kesamaan hak.

Pelayanan yang tidak melakukan diskriminasi dilihat dari aspek apapunkhususnya suku, ras, agama, golongan, status sosial dan lain-lain.

6. Keseimbangan hak dan kewajiban

Pelayanan yang mempertimbangkan aspek keadilan antara pemberi danpenerima pelayanan publik.

Mengacu pada data di atas, maka dapat dikatakan bahwa kinerja pegawai di Kelurahan Sako Kota Palembang berpengaruh positif terhadap efektivitas pelayanan publik. Artinya dengan kinerja pegawai yang mempunyai kualitas dan kuantitas pelayanan yang baik, maka pelayanan publik dapat berjalan dengan baik. Selaras dengan hal tersebut, maka dapat menciptakan kinerja yang maksimal untuk mewujudkan kepuasan masyarakat terhadap pelayanan publik akan terpenuhi.

\section{PENUTUP}

\section{KESIMPULAN}

Berdasarkan hasil penelitian dapat disumpulkan bahwa pengaruh kinerja terhadap efektivitas pelayanan pada kantor Kelurahan Sako Kota Palembang adalah positif. Artinya dengan kinerja pegawai yang mempunyai kualitas dan kuantitas pelayanan yang baik, maka pelayanan publik dapat berjalan dengan baik pula. Selaras dengan hal tersebut, maka dapat menciptakan kinerja yang maksimal untuk mewujudkan kepuasan masyarakat terhadap pelayanan publik akan terpenuhi.

\section{DAFTAR PUSTAKA}

Abdurahmat. 2003. Pemanfaatan Sumber
Daya Manusia. Jakarta : PT.Gramedia.

A. Nasution. 2001.Manajemen Pelayanan Publik. Jakarta : PT. Gramedia.

Mangkunegara,Retno. 2007. Manajemen Sumber Daya Manusia. Surabaya : Sumber Abadi.

Moenir. 2000.ManajemenPelayananPublik. Jakarta : Bina Aksara.

Ratminto. 2005. Efektivitas Pelayanan Publik. Bandung : Mandar Maju.

Stephen P. Robins. 2002 .Perilaku Organisasi. Jakarta : Prenhallindo. 
2003. Perilaku Organisasi.Jakarta :

Prenhallindo.

Sedarmayanti. 2007. Prilaku Administrasi. Jakarta : PT. BumiAksara.

Sondang. P. Siagian,2001.DefinisiEfektifitas. Jakarta : PT Bumi aksara.

Sinambela, dkk. 2010. Manajemen Pelayanan Umum. Jakarta : PT.Gramedia.

Sugiyono. 2003. Metode penelitian administrasi. Bandung : Alfabeta.

2006. Metode penelitian administrasi.

Bandung : Alfabeta.

2013. Metode penelitian administrasi.

Bandung: Alfabeta

Keputusan Menteri Pendayagunaan Aparatur Negara. Republik Indonesia Nomor : 63 / Kep/M.Pan /7 /2003 Tentang Pendoman Umum Penyelenggaraan.

\section{DAFTAR PUSTAKA}

(2020). Bahan Paparan Sekretaris Daerah: Kebijakan Refocusing dan Realokasi Anggaran 2020. Provinsi Kepulauan Bangka Belitung.

Dwiyanto, A. (2015). Manajemen Publik : Peduli, Inklusif, dan Kolaboratif. Yogyakarta: Gadjah Mada University Press.

Junita, A. (2015). Faktor-Faktor yang Mempengaruhi Perubahan Anggaran pada Pemerintahan Daerah. Jurnal Manajemen dan Keuangan, Vol. 4, o.2 November.

Kumorotomo, W. (2018). Politik Anggaran di Indonesia. Yogyakarta: PT Jogja Power.

Rachma, M. Y. (2005). Determinan Belanja Pegawai pada Pemerintahan Kabupaten/Kota di Provinsi Jambi. Jurnal Perspektif Pembiayaan dan Pembangunan Daerah, Vol. 4 No. 3, Januari-Maret 2017.

Rubin, I. S. (1990). Budget Theory and Budget Practice: How good the Fit. Chatham New Jersey: Chatham House Publishers.

Sanjaya, N. (2020). Kebijakan Penganggaran Daerah di Masa Pandemi Covid-19 (Study Kasus pada Pemerintahan
Provinsi Banten. Jurnal Ilmu Administrasi Media Pengembangan Ilmu dan Praktek Administrasi, Volume 17 Nomor 2, Desember 2020.

Siagian. (1999). Patologi Birokrasi : Analisis, Identifikasi dan Terapinya. Jakarta: Jakarta Ghalia.

Wahyudi Kumorotomo; Erwan Agus Purwanto (ed). (2005). Anggaran Berbasis Kinerja Konsep dan Aplikasinya. Yogyakarta: Magister Administrasi Publik Universitas Gadjah Mada.

Yuningsing, T. (. (2018). Etika Administrasi Publik.

Semarang: Program Doktor Administrasi, Publik Press FISIP UNDIP.

https://tirto.id/menilik-masifnya-alokasi-belanjapegawai-pemerintah-daerah-emtP https://syukriy.wordpress.com/2012/11/26/hubungankeagenan-antara-kepala-daerah-dan-kepala-skpd/ https://www.cnbcindonesia.com/news/20191114193254 $-4-115387 /$

https://babelprov.go.id/content/perubahan-apbd-tahun2020-refocusing-dan-realokasi-anggaran-penanganancovid-19

https://babel.bps.go.id/pressrelease/2020/05/05). https://ekonomi.bisnis.com/read/20190719/10/1 126443/alokasi-apbd-paling-dominan-untukbelanja-pegawai-

https://www.cnbcindonesia.com/news/20191114193254 -4-115387/data-mengejutkan-sri-mulyani-70-apdbhabis-untuk-pns-pem 
